\title{
FIRST OCCURRENCE OF THE BLACKSPOT CONGER, PARACONGER MACROPS (ACTINOPTERYGII: ANGUILLIFORMES: CONGRIDAE), IN THE WATERS OF THE CANARY ISLANDS: A COMPARATIVE STUDY OF EASTERN ATLANTIC PARACONGER SPECIES
}

\author{
Sergio MORENO-BORGES ${ }^{1 *}$, Alejandro ESCÁNEZ ${ }^{1,2}$, and Alberto BRITO1 \\ ${ }^{1}$ Grupo BIOECOMAC, Departamento de Ciencias Marinas, Universidad de La Laguna, \\ San Cristóbal de La Laguna, Santa Cruz de Tenerife, Canary Islands, Spain \\ ${ }^{2}$ Departamento de Ecoloxía e Bioloxía Animal, Edificio de Ciencias Experimentais, Campus As Lagoas Marcosende, \\ Universidade de Vigo, Vigo, Spain
}

\begin{abstract}
Moreno-Borges S., Escánez A., Brito A. 2019. First occurrence of the blackspot conger, Paraconger macrops (Actinopterygii: Anguilliformes: Congridae), in the waters of the Canary Islands: A comparative study of eastern Atlantic Paraconger species. Acta Ichthyol. Piscat. 49 (1): 89-93.
\end{abstract}

\begin{abstract}
The blackspot conger, Paraconger macrops (Günther, 1870), is a Macaronesian endemic species, hitherto known for Madeira and Azores. This work, based on by an extensive classical and molecular systematic study of one specimen captured by scuba-diving at El Hierro, provides evidence of its presence in the Canary Islands. A comparative study of the Paraconger species inhabiting the eastern Atlantic is presented.
\end{abstract}

Keywords: Canary Islands, first occurrence, Paraconger, morphological and molecular study, eastern Atlantic.

\section{INTRODUCTION}

The genus Paraconger was described by Kanazawa (1961) and it presently includes a total of 7 species (Froese and Pauly 2018). Only three of them are recorded for the eastern central Atlantic (Smith 2016): the margintail conger, Paraconger caudilimbatus (Poey, 1867), the blackspot conger, Paraconger macrops (Günther, 1870), and the Guinean conger, Paraconger notialis Kanazawa, 1961. These species have warm-temperate or tropical affinities, because, until recently, $P$. macrops had been considered an endemic species of the Azores and Madeira and $P$. notialis is known to inhabit waters from Senegal, through Cabo Verde Islands, to Angola (Blache 1976, Saldanha 1981, Brito et al. 1999, Smith 2016). Paraconger caudilimbatus inhabits predominantly the western Atlantic. Wirtz et al. (2007), however, reported the presence of several specimens of this species in the São Tomé and Príncipe Islands (Gulf of Guinea, eastern Atlantic). According to previous reports, the earlier mentioned three species inhabit sandbanks below the $20-\mathrm{m}$ isobath, being buried during the daylight and hunting preys during the night (Blache 1976, Bauchot and Saldanha 1986, Brito et al. 2017). The three species can be easily separated from each other thanks to a series of morphological and meristic characters (Table 1).

Recently, Brito et al. (2017) reported for the first time the presence of a Paraconger species at El Hierro (Canary
Islands) based on a photograph taken in one sandy-bottom locality in the spring of 2017. This individual was then tentatively identified as a Paraconger cf. macrops, based on its general appearance, and in this paper, we show the outcome of an extensive taxonomic study of one specimen captured at the same locality in October 2017 and confirm the presence of this species.

\section{MATERIAL AND METHODS}

One scuba-diving survey was carried out on 31 October 2017, during the daylight at El Desierto $\left(27^{\circ} 40.74^{\prime} \mathrm{N}, 18^{\circ} 01.92^{\prime} \mathrm{W}\right.$, near the external border of La Restinga-Mar de las Calmas Marine Reserve, El Hierro).

Two specimens of Paraconger macrops from the Museu de História Natural do Funchal (MMF) and the only specimen of $P$. caudilimbatus collected in São Tomé by Wirtz et al. (2007) from the Staatliches Museum für Naturkunde Stuttgart (SMNS) were used for comparison (Table 1).

Specimens were measured to the nearest $1 \mathrm{~mm}$ (Kanazawa 1961). In order to identify the species, the main characters used were the presence of supratemporal pores, the number of pores in the lateral line anterior to the anus, the total number of vertebrae, the presence of one black spot at the beginning of the dorsal fin, and the

* Correspondence: Mr. Sergio Moreno, BIOECOMAC, U D. de Ciencias Marinas, Universidad de La Laguna. Avenida Astrofísico Francisco Sánchez, s/n San Cristóbal de La Laguna. S/C de Tenerife, Canary Islands, Spain, phone: (+34) 922318387, e-mail: (SMB) smorenob@ull.edu.es, (AE) aescanez@msn.com, (AB)abrito@ull.es. 
Table 1

Diagnostic characters of Paraconger caudilimbatus, Paraconger notialis, and Paraconger macrops, based on the presently reported study and published data

\begin{tabular}{|c|c|c|c|c|c|c|}
\hline \multirow{2}{*}{ Character } & \multirow{2}{*}{$\begin{array}{c}\text { P. caudilimbatus } \\
\text { SMNS } 25228\end{array}$} & \multirow{2}{*}{$\frac{\text { P. notialis }}{\text { REF A }}$} & \multicolumn{4}{|c|}{ P. macrops } \\
\hline & & & REF B & MMF 27154 & MMF 5251 & TFMCBMV/01956 \\
\hline $\mathrm{TL}[\mathrm{mm}]$ & 85.5 & $289-605$ & $245-449$ & 345 & 347 & 402 \\
\hline LL pores anterior to anus & 45 & $34-44$ & $48-53$ & 48 & 50 & 49 \\
\hline Vertebrae (Total) & - & $132-137$ & $144-147$ & 145 & 145 & 141 \\
\hline Supratemporal pore & Present & Absent & & & Present & \\
\hline $\begin{array}{l}\text { Black spot at beginning of } 1 \mathrm{st} \\
\text { dorsal fin }\end{array}$ & Absent & Absent & & & Present & \\
\hline $\begin{array}{l}\text { Position of upper edge of gill } \\
\text { opening (in relation to pectoral } \\
\text { fin base) }\end{array}$ & Not above & Not above & & & Above & \\
\hline
\end{tabular}

REF A = Kanazawa (1961) and Blache (1976), REF B = Kanazawa (1961), Saldanha (1981), Blache and Bauchot (1976), SMNS 25228, MMF 27154, MMF 5251, TFMCBMV/01956 are specimens examined in the course of the presently reported study; TL = total length, $\mathrm{LL}=$ lateral line.

position of the upper edge of the gill opening in relation to the pectoral fin (Kanazawa 1961, Blache 1976, Smith 2016). X-ray images of the specimens were taken to count the vertebrae.

DNA was isolated from pectoral fin tissue using the phenol-chloroform protocol (Sambrook et al. 1989). The amplified sequence corresponded with the 5 ' region of the coxl gene from mitochondrial DNA using the designed primers by Ward et al. (2005):

FishF1-5'-TCAACCAACCACAAAGACATTGGCAC-3' FishR2-5'-ACTTCAGGGTGACCGAAGAATCAGAA-3'

PCR amplifications were performed with a thermal regime consisting of an initial step of $2 \mathrm{~min}$ at $95^{\circ} \mathrm{C}$ followed by 35 cycles of $0.5 \mathrm{~min}$ at $94^{\circ} \mathrm{C}, 0.5 \mathrm{~min}$ at $57^{\circ} \mathrm{C}$, and $1 \mathrm{~min}$ at $72^{\circ} \mathrm{C}$, followed in turn by $10 \mathrm{~min}$ at $72^{\circ} \mathrm{C}$ and then maintained at $4^{\circ} \mathrm{C}$. PCR products were visualized on $1.5 \%$ agarose gels. The sample was purified and sequenced with Stabvida (Oeiras, Portugal).

DNA sequences were edited and assembled using MEGA v.7 (Kumar et al. 2016). Sequence alignment was performed using CLUSTAL W (Thompson et al. 1994) as implemented in MEGA. jModelTest 2.1.10 (Darriba et al. 2012) was used to identify the appropriated nucleotide substitution model employing the Bayesian information criterion (BIC) (Schwarz 1978). Phylogenetic relations were studied by maximum likelihood (ML) analysis using RAxML 7.2.8 (Stamatakis 2006) and Bayesian analysis implemented in MR.BAYES 3.2.1 (Ronquist et al. 2012) with the online platform Mobyle SNAP Workbench (Monacell and Carbone 2014). The visualization and edition of the tree was developed with FigTree v1.4.0.

\section{RESULTS}

A total of six specimens of Paraconger macrops (Fig. 1A) were spotted during the survey; all of them were completely buried in the sediment or only partially showing the snout (Fig. 1B). All specimens were found sharing habitats with the brown garden eel, Heteroconger longissimus Günther, 1870. One individual was captured at the depth of $20 \mathrm{~m}$ and $23^{\circ} \mathrm{C}$ ambient temperature.

Diagnostic characters employed in the meristic and anatomic study were highly informative. Paraconger macrops from the Azores and Madeira (MMF 27154 and 5251) clearly showed the upper edge of the gill opening over the pectoral fin, one black spot covering the first rays of the dorsal fin and many pores in the lateral line anterior to the anus from 48 to 50 pores (Table 1). These characters matched those of the specimen captured in El Hierro (Fig. 1A, 1C), while $P$. caudilimbatus had a lower number of pores in the lateral line and its gill opening was at the same level as the upper part of the pectoral fin base. Additionally, it did not show the black spot in the dorsal fin.

$\mathrm{X}$-ray images were taken from all Paraconger macrops specimens, but it was not possible to do it with $P$. caudilimbatus due to its small size. The number of vertebrae was the same for the specimens from Azores and Madeira, being slightly lower for the fish from the Canary Islands (Table 1).

All the fish showed one supratemporal pore exactly in the middle point between the first pores of the lateral line (Fig. 1C).

Out of the 4 specimens under examination (Table 1), it was only possible to sequence the eel captured in El Hierro, and the information was deposited in GenBank (accession number: MH428009). Paraconger macrops from the Azores and Madeira probably had been fixed in formaldehyde so the DNA was corrupted, and it was not possible to extract enough tissue from $P$. caudilimbatus without damaging it considerably.

After sequencing our sample for the mitochondrial gene coxl (639 bp) we constructed a matrix of sequences with eighteen additional sequences from GenBank (fourteen belonging to $P$. caudilimbatus, three to $P$. notialis, and one to $H$. longissimus as outgroup) in order to determine 
the relations of our specimen with the other two species occurring in the eastern Atlantic Ocean-Paraconger notialis and $P$. caudilimbatus. However, P. macrops had not been sequenced before and therefore the purpose of these analyses was to know whether our specimen's characters matched those of the other species, included in the phylogenetic tree. If they did not match it would suggest that we dealt with a different species.

The phylogenetic trees obtained by MaximumLikelihood and Bayesian analyses recovered the same topology (Fig. 2) with two strongly supported clades corresponding to the eel captured at El Hierro (BI posterior probability/ML bootstrap $\%=0.99 / 100 \%$ ) and the second one with the 3 specimens classified as Paraconger notialis (1/100\%), both clearly differentiated from outgroup $H$. longissimus. Sequences from $P$. caudilimbatus were grouped together but it was only slightly supported by the Bayesian analysis (0.85) (Fig. 2). Consequently, with the phylogenetic trees we determined that the studied specimen from El Hierro was a different species than $P$. notialis and $P$. caudilimbatus.

\section{DISCUSSION}

Paraconger macrops can be easily separated from the other Atlantic species belonging to the genus Paraconger (see Kanazawa 1961) thanks to a series of meristic and morphological characters (Table 1). Paraconger guianensis Kanazawa, 1961, also an Atlantic species, was not included in the comparison as it is readily separated from the other three Atlantic species by its lower number of lateral line pores prior to the anus (31-36) and of vertebrae (127-131).

However, the X-ray image of the whole specimen allowed us to count a total 141 vertebrae (Table 1); this number slightly differs from the values usually found in P. macrops-from 144 to 147 (Kanazawa 1961, Blache 1976, Saldanha 1981). On the other hand, in $P$. notialis and $P$. caudilimbatus the number of vertebrae ranges from 131 to 138 and 120 to 127, respectively (Kanazawa 1961, Blache 1976, Robins 1989). It is possible that the value range found in published sources was based only on 13 specimens of $P$. macrops and, therefore, its variability may be currently unknown.

Finally, we assessed the phylogenetic relation of our specimen with all available sequences in GenBank. The resulting phylogenetic tree separated our Paraconger specimen from all the remaining species. Fortunately, despite the lack of available sequences of the majority of the species belonging to this genus, $P$. caudilimbatus and $P$. notialis have previously been sequenced, allowing us to disregard them during the identification process, especially because these species were the other possible species.

In the light of the results of this study, there is a significant evidence of the morphological and meristic characters to support the identity of our specimen as a Paraconger macrops. It is reasonable to assume that this species inhabits the Canary Islands waters since it is a Macaronesian endemic species previously reported for the Azores and Madeira (Kanazawa 1961, Blache 1976, Saldanha 1981). This species-specific behaviour (Bauchot and Saldanha 1986) (Fig. 1C) could be one explanation for why it has gone unnoticed over the years. The followup studies should focus on the presence of P. macrops in the remaining islands of the Canarian Archipelago and compare our specimens with fresh $P$. macrops from the Azores and Madeira through molecular analysis. This way, the origin of $P$. macrops from the Canary Islands and its relation to the surrounding population will be clarified.

\section{ACKNOWLEDGEMENTS}

This study was funded by MARE (UID/ MAR/04292/2013)_FundaçãoparaaCiênciaeaTecnologiaFCT (partially FEDER funded); Fundación CajaCanarias by the support of the project: "Efectos del cambio climático sobre los ecosistemas marinos litorales de Canarias: Indicadores de tropicalización" (INDICATROP) and by the Erasmus+ Programme as a project developed during a 3-months traineeship of the first author.

We are very grateful to Dr Stefan Merker from the Staatliches Museum für Naturkunde Stuttgart as well as Dr Manuel Biscoito from the Museu de História Natural

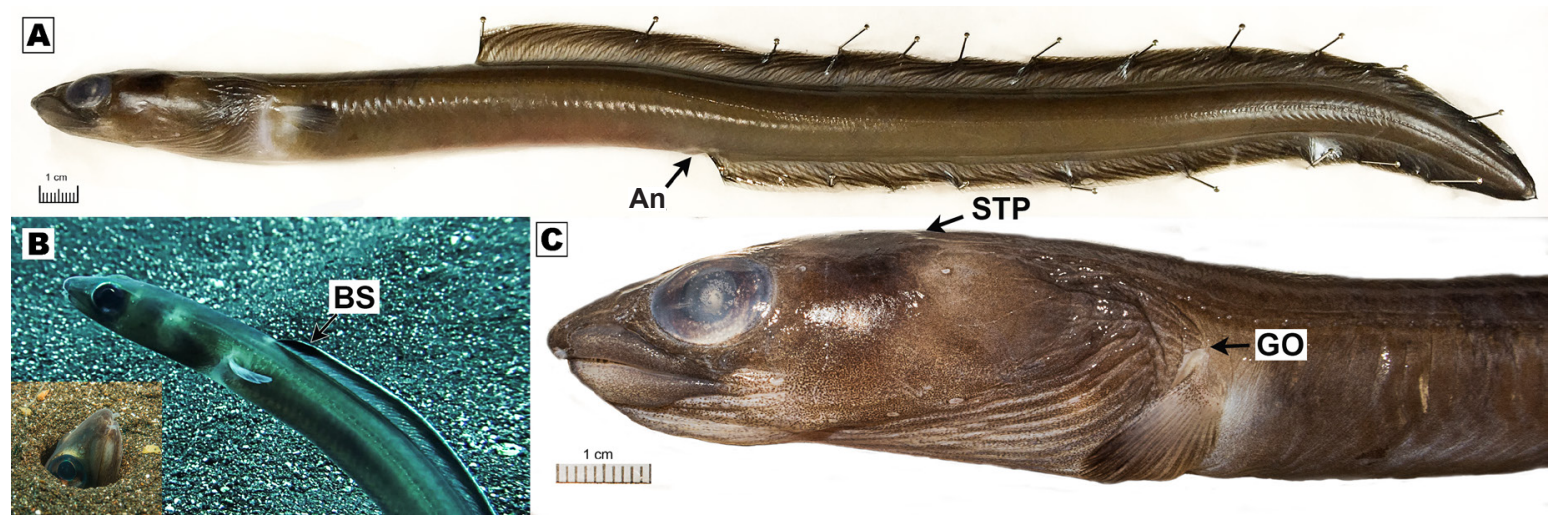

Fig. 1. Paraconger macrops; entire specimen from El Hierro (TFMCBMVP/01956) (A); two different individuals sighted during the submarine survey (B) featuring a close-up of the snout (left corner), and the black spot in the beginning of its dorsal fin first section of the body of the other specimen; a close up of the anterior part of the body (TFMCBMVP/01956) (C); An = anus, BS = black spot, GO = gill opening, $\mathrm{STP}=$ supratemporal pore 


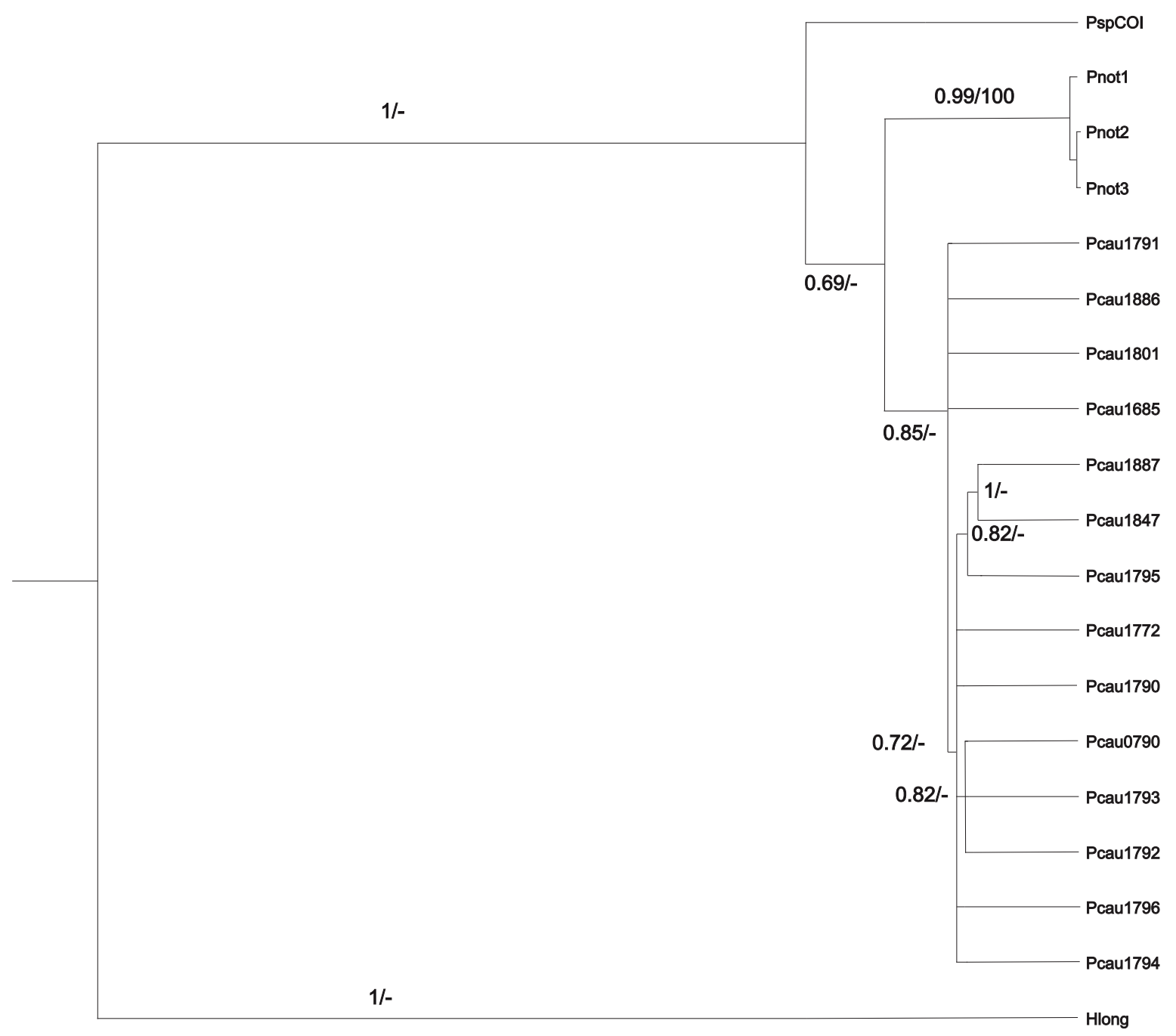

Fig. 2. Phylogenetic relations within the genus Paraconger using the cox 1 region; for each branch, numbers at the left represent the posterior probabilities for Bayesian inference and at the right the bootstrap values obtained for ML (only values around $70 \%$ or higher) are indicated; Hlongi $=$ Heteroconger longissimus (used as outgroup); Pcau $=$ Paraconger caudilimbatus, Pnot $=$ Paraconger notialis, Psp $=$ specimen from El Hierro

do Funchal for making available the specimens used the presently reported study. We thank to María del Mar Brito for the English revision of the text.

\section{REFERENCES}

Bauchot M.L., Saldanha L. 1986. Congridae (including Heterocongridae). Pp. 567-574. In: Whitehead P.J.P., Bauchot M.-L., Hureau J.-C., Nielsen J., Tortonese E. (eds). Fishes of the north-eastern Atlantic and the Mediterranean. Volume 2. UNESCO, Paris.

Blache J. 1976. Contribution à la connaissance des poissons anguilliformes de la côte occidentale d'Afrique. Première note: Enchelycore nigricans (Bonnaterre 1788). [Muraenidae]. Bulletin de IFAN ser. A. 38 (1): 369-443.

Brito A., Herrera R., Falcón J.M., García-Charton J.A., Barquín J., Pérez-Ruzafa A. 1999. Contribución al conocimiento de la ictiofauna de las Islas de Cabo
Verde. Revista de la Academia Canaria de Ciencias 11 (3-4): 27-41.

Brito A., Moreno-Borges S., Escánez A., Falcón J.M., Herrera R. 2017. New records of actinopterygian fishes from the Canary Islands: Tropicalization as the most important driving force increasing fish diversity. Revista de la Academia Canaria de Ciencias 29 (1): 31-44.

Darriba D., Taboada G.L., Doallo R., Posada D. 2012. jModelTest 2: more models, new heuristics and parallel computing. Nature Methods 9: e772. DOI: 10.1038/ nmeth.2109

Froese R., Pauly D. (eds.) 2018. FishBase. [Version 06/2018] http://www.fishbase.org

Kanazawa R.H. 1961. Paraconger, a new genus with three new species of eels (family Congridae). Proceedings of the United States National Museum 113 (3450): 1-14. DOI: 10.5479/si.00963801.113-3450.1 
Kumar S., Stecher G., Tamura K. 2016. MEGA7: Molecular evolutionary genetics analysis Version 7.0 for bigger datasets. Molecular Biology and Evolution 33 (7): 1870-1874. DOI: 10.1093/ molbev/msw054

Monacell J.T., Carbone I. 2014. Mobyle SNAP Workbench: A web-based analysis portal for population genetics and evolutionary genomics. Bioinformatics 30 (10): 1488-1490. DOI: 10.1093/ bioinformatics/btu055

Robins C.R. 1989. The phylogenetic relationships of the anguilliform fishes. Pp. 9-23. In: Böhlke E.B. (ed.) Fishes of the western North Atlantic. Part 9, Volume 1. Orders Anguilliformes and Saccopharyngiformes. Memoir of the Sears Foundation for Marine Research. Yale University Press, New Haven CT, USA.

Ronquist F., Teslenko M., van der Mark P., Ayres D.L., Darling A., Höhna S., Larget B., Liu L., Suchard M.A., Huelsenbeck J.P. 2012. MrBayes 3.2: Efficient Bayesian phylogenetic inference and model choice across a large model space. Systems Biology 61 (3): 539-542. DOI: 10.1093/sysbio/ sys029

Saldanha L. 1981. Presence de Paraconger macrops (Günther, 1870) aux Açores (Pisces, Congridae). Cybium 5 (2): 95-97.

Sambrook E., Fritsch F., Maniatis T. 1989. Molecular cloning. 2nd edn. Cold Spring Harbor Laboratory Press, Cold Spring Harbor NY, USA.
Schwarz G. 1978. Estimating the dimension of a model. Annals of Statistics 6 (2): 461-464.

Smith D.G. 2016. Congridae. Pp. 1680-1694. In: Carpenter K.E., De Angelis N. (eds.) The living marine resources of the eastern central Atlantic. Volume 3: Bony fishes part 1 (Elopiformes to Scorpaeniformes). FAO Species Identification Guide for Fishery Purposes. FAO, Rome.

Stamatakis A. 2006. RAxML-VI-HPC: maximum likelihood-based phylogenetic analyses with thousands of taxa and mixed models. Bioinformatics 22 (21): 2688-2690. DOI: 10.1093/bioinformatics/ bt1446

Thompson J.D., Higgins D.G., Gibson T.J. 1994. CLUSTAL W: improving the sensitivity of progressive multiple sequence alignment through sequence weighting, position-specific gap penalties and weight matrix choice. Nucleic Acids Research 22 (22): 4673-4680. DOI: 10.1093/nar/22.22.4673

Ward R.D., Zemlak T.S., Innes B.H., Last P.R., Hebert P.D.N. 2005. DNA barcoding Australia's fish species. Philosophical Transactions of the Royal Society B, Biological Sciences 360 (1462): 1847-1851. DOI: 10.1098/rstb.2005.1716

Wirtz P., Ferreira C.E.L., Floeter S.R., Fricke R., Gasparini J.L., Iwamoto T., Rocha L., Sampaio C.L.S., Schliewen U.K. 2007. Coastal fishes of São Tomé and Príncipe islands, Gulf of Guinea (eastern Atlantic Ocean)-An update. Zootaxa 1523: 1-48. DOI: $10.5281 /$ zenodo. 177470

Received: 11 July 2018

Accepted: 4 October 2018

Published electronically: 15 March 2019 